\title{
Buk zwyczajny (Fagus sylvatica) „Sobieski” - przyrodniczy pomnik Górnego Śląska
}

\author{
PIOTR Muras
}

\begin{abstract}
Muras, P. 2020. The European beech (Fagus sylvatica) "Sobieski" - a nature monument in Upper Silesia. Fragmenta Floristica et Geobotanica Polonica 27(2): 83-93. Kraków. e-ISSN 2449-8890, ISSN 1640-629X.

Aвstract: One of the oldest beeches in Poland, called "Sobieski" (trunk circumference $732 \mathrm{~cm}$ ), growing on the Rybnicki Plateau on private property in Świerklany Dolne, was studied as part of a project entitled "Documentation, Analysis and Landscape Design". Research on the tree's condition began in 2009. In 2017 a sample from a broken bough was taken for dendrological analysis. In 2018 the condition of the trunk condition was evaluated using a PiCUS tomograph. Study of forest areas in the middle part of the Rybnicki Mesoregion revealed the presence of a group of magnificent beeches. The Jankowicki Forest complex is $2 \mathrm{~km}$ away from the "Sobieski" tree, so a genetic relationship is highly probable. Gene samples were taken to assess the degree of genetic relationship or to find unique alleles characteristic for the tree monument. As the Moravian Gate is nearby, Czech studies on tree monuments in eastern Moravia were analysed. A search of archives focused on the historical links between "Sobieski" growing near the no longer extant Kundlauer Manor and the march of King John III Sobieski’s army through Upper Silesia in 1683.
\end{abstract}

KEY WORDS: diagnosis of destruction, monumental beech, Poland, Upper Silesia

P. Muras, Katedra Roślin Ozdobnych i Sztuki Ogrodowej, Wydziat Biotechnologii i Ogrodnictwa; Uniwersytet Rolniczy w Krakowie, Al. 29 Listopada 54, 31-425 Kraków, Polska; e-mail: romuras@cyf-kr.edu.pl

\section{WSTEP}

Buk zwyczajny (Fagus sylvatica L.) ,Sobieski”, rosnący na prywatnej posesji w Świerklanach Dolnych, w południowej części Płaskowyżu Rybnickiego $\left(18^{\circ} 34,998^{\prime} \mathrm{E}, 50^{\circ} 1,326^{\prime} \mathrm{N}\right)$, jest jednym z najstarszych w Polsce okazów buka formy nominatywnej (Ryc. 1). Odnotowano go w monografii buka zwyczajnego Instytutu Dendrologii PAN (BıАŁOBoK 1990), gdyż już wtedy był jednym z największych okazów w kraju. W 1962 r., gdy drzewo uznano za pomnik przyrody, obwód jego pnia wynosił $565 \mathrm{~cm}$, a wysokość $22 \mathrm{~m}$. Ujęto go w zbiorze drzew pomnikowych Płaskowyżu Rybnickiego (URBISz 2002), oraz w opracowaniu Drzewa Polski. Najgrubsze, najstarsze, najstynniejsze (ZARZYŃSKI i in. 2016), jako najgrubszy buk rosnący na Śląsku, szacując jego wiek na 330 lat. Przytoczono też legendę o „Sobieskim”, funkcjonującą w miejscowej tradycji i związaną z przemarszem oddziałów Jana III Sobieskiego pod Wiedeń przez tę część Śląska, należącego wówczas do Monarchii Habsburgów 


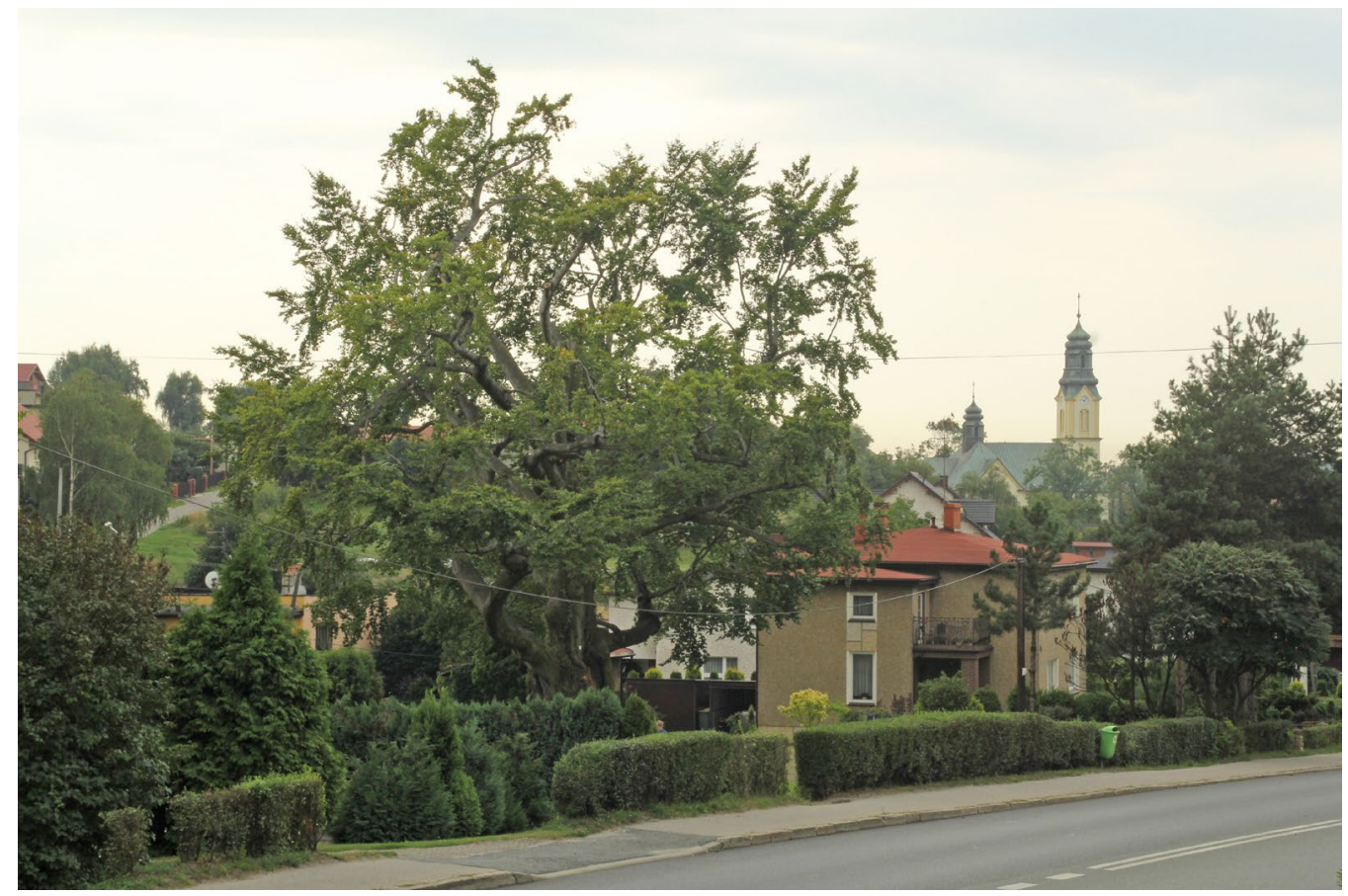

Ryc. 1. Buk „Sobieski” w Świerklanach Dolnych - widok z drogi wojewódzkiej 932; sierpień 2018 r. (fot. P. Muras)

Fig. 1. The "Sobieski" beech in Świerklany Dolne, seen from the Provincial Road 932; August 2018 (photo P. Muras)

(PIWARSKI 1934; KRUPA 2013). Istnienie historycznego buka przy nieistniejącym obecnie dworze Smyczyka (do 1897 r. Kundlauera), odnotowano dwukrotnie w publikacjach poświęconych historii Świerklan (ZıMOŃCZYK 1998a, b). Drzewo rośnie przy wczesnośredniowiecznym szlaku, wiodącym z Krakowa, przez Pszczynę, Żory, Nysę do Wrocławia, albo przez Kotlinę Kłodzką i Nachod do Pragi.

Celem niniejszych badań było udokumentowanie stanu buka „Sobieski” pod względem zewnętrznych uszkodzeń pnia, konarów i całej korony, obecności widocznych fragmentów zgnilizny drewna oraz zaawansowania wewnętrznej destrukcji pnia i osłabienia jego struktury.

\section{OPIS REGIONU I STANOWISKA}

Obszar Świerklan znajduje się w południowej części Mezoregionu Płaskowyżu Rybnickiego. Stanowi on południowo-zachodnią część Wyżyny Śląskiej (KoNDRACKI 2000), jest mocno urozmaicony - stosunkowo strome pagórkowate fragmenty przedzielają głęboko wcięte wilgotne doliny, które przyjmują niekiedy formy parowów i jarów. Różnica wzniesień w tym terenie sięga 20-40 m, a spadki terenu 10-20\%. Rzeźba ta jest efektem intensywnego działania lądolodu. W południowej części Płaskowyżu Rybnickiego na podłożu piasków, żwirów wodnolodowcowych lub rzecznych, piasków i pospółek gliniastych, zalegają pyły lessowe. Są formacją wilgotną, przejściową, silnie piaszczystą 
o niskiej porowatości i wysokiej wilgotności naturalnej i kwaśnym odczynie (FOLTYN \& FOLTYN 2017).

Na obszarze Świerklan Dolnych dominują utwory ilaste i lessopodobne. W dolinie rzeki Szotkówki rozwinęły się bardzo żyzne mady czarnoziemne, wytworzone z pyłów ilastych, osadzone często na warstwach nieprzepuszczalnych, co czyni je trudnymi w uprawie w lata mokre, równocześnie stwarzając idealne warunki dla stawów, funkcjonujących tam od czasów średniowiecznych (MusioŁ 1959). Szeroka i płaskodenna dolina stosunkowo łagodnie opada w kierunku Doliny Olzy (zlewnia Odry). Wyspowo wzdłuż Szotkówki występuje olsza czarna Alnus glutinosa. Jeszcze w latach 70. XX w. wzdłuż drogi wojewódzkiej 932, zanim została przebudowana, rosły dorodne jesiony. W tym fragmencie doliny potencjalną roślinnością naturalną jest niżowy łęg jesionowo-olszowy (Fraxino-Alnetum). Ogólnie na obszarze południowego fragmentu Płaskowyżu Rybnickiego, w tym Świerklan (z wyjątkiem wilgotnych fragmentów dolin), według mapy potencjalnej roślinności naturalnej, rozciąga się teren występowania żyznych buczyn niżowych (Melico-Fagetum) (MATUSZKIEWICz 2008; SENETA \& DolatowsKi 2009). W materiałach Nadleśnictwa Rybnik podano, że lesistość mezoregionu Rybnickiego jest mała i wynosi $12 \%$. W okolicach Wodzisławia (na zachód do Świerklan) dominuje krajobraz grądów i buczyn (PlAn URZĄDZENIA LASU 2016).

Okolice Świerklan pod względem klimatycznym należą do najcieplejszej części Wyżyny Śląskiej. Zimy są łagodne, długość okresu wegetacyjnego trwa 200-220 dni, a lato około $100 \mathrm{dni}$. Średnia roczna temperatura powietrza wynosi $7,8^{\circ} \mathrm{C}$. Dni mroźnych przypada od 20 do $40 \mathrm{w}$ roku, a z przymrozkami od 100 do 130. Ostatnie wiosenne przymrozki występują zwykle do trzeciej dekady kwietnia (w obniżeniach terenu do drugiej dekady maja). Przymrozki jesienne pojawiają się od drugiej lub trzeciej dekady października. Średnio w ciągu roku pokrywa śnieżna utrzymuje się od 40 do 55 dni. Większa niż w innych częściach Górnego Śląska jest roczna suma opadów wynosząca 800 mm, co wynika z bliskości Bramy Morawskiej, przez którą z południa napływają wilgotne i ciepłe masy powietrza. Średnia wilgotność względna powietrza wynosi $80 \%$. Przeważają tutaj wiatry z kierunków południowych i zachodnich (60\%), (ŚwIERKLANY 2018).

Na Płaskowyżu Rybnickim rośnie 300 okazów drzew o wymiarach pomnikowych, należących do 25 gatunków. Dominują dęby szypułkowe (88), buki zwyczajne (81) i lipy drobnolistne (38). Okazałe drzewa występują głównie na terenie dawnych parków dworskich lub w pobliżu kościołów i na przydrożach. Rzadko spotykane są w obrębie zwartych kompleksów leśnych (URBISz 2002).

Buk „Sobieski” rośnie w dolinie Szotkówki na żyznym terenie ze stałym dostępem do wody. Miejsce jest dobrze osłonięte od wiatrów północno-zachodnich i wschodnich. Dolina na kilkuset metrach obniża się tutaj od około $285 \mathrm{~m}$ do $265 \mathrm{~m}$ n.p.m. w rejonie kościoła w Świerklanach Dolnych.

\section{MATERIAE I METODY}

Badania dendrometryczne buka „Sobieski” oraz dokumentację fotograficzną prowadzono od $2009 \mathrm{r}$. (Ryc. 2-4). W urzędzie Gminy Świerklany uzyskano informacje dotyczące oceny stanu sanitarno-zdrowotnego buka i działań profilaktycznych pielęgnacyjno-konserwatorskich zlecanych i finansowanych przez 
gminę. Dzięki pomocy właścicieli posesji, na której rośnie buk „Sobieski”, zebrano dokumentację i informacje dotyczące drzewa oraz fragmenty odpadłych konarów.

W sierpniu 2018 r. przeprowadzono wizualną ocenę stanu całej korony buka „Sobieski” oraz zewnętrznych uszkodzeń pnia i konarów pod kątem obecności widocznych fragmentów zgnilizny drewna. Równocześnie pracownicy firmy Taxus Arbor w Tychach wykonali tomografem PiCUS ocenę wewnętrznej destrukcji pnia i osłabienia jego struktury. Badania stanu pnia przeprowadzono na czterech wysokościach od poziomu gruntu: $35 \mathrm{~cm}$ - tuż powyżej odziomka; $75 \mathrm{~cm}$ i $150 \mathrm{~cm}$ - gdzie pień wytworzył regularny walec oraz $350 \mathrm{~cm}$ - powyżej zgrubienia pnia, z którego wyrastają zasadnicze konary (Ryc. 2) (CHOMICz 2010; MilbRANDT \& KÖHLER 2015).

\section{WYNIKI I DYSKUSJA}

Buk zwyczajny na ziemie polskie dotarł w holocenie i rozprzestrzenił się w warunkach dogodnego klimatu na obszarach uwolnionych od cienioznośnych gatunków przez człowieka przedhistorycznego (BORATYŃSKA \& BORATYŃSKI 1990). W południowej części Płaskowyżu Rybnickiego większość buków została wycięta w średniowieczu w następstwie procesu osadniczego (MusioŁ 1959).

Buk „Sobieski” posadzono po południowo-zachodniej stronie nieistniejącego już dziś dworu na nieznacznie wyniesionym pagórku. Usytuowanie na froncie budynku, w nieznacznej odległości od drogi (około 20 m), wskazuje jednoznacznie, że wybór był przemyślany (Ryc. 1). Buk „Sobieski” dominuje w krajobrazie i charakteryzuje się typowym dla drzew wyrosłych na otwartej przestrzeni krótkim masywnym pniem z napływami korzeniowymi (BORATYŃSKA \& BORATYŃSKI 1990).

Na wysokości 4-5 m buk ,Sobieski” rozgałęzia się na wiele grubych konarów, budujących rozłożystą koronę. Jego pień jest walcowaty i dosyć regularny do wysokości 2-3 m. Zasadnicze I piętro - na wysokości 3-4 m - tworzyło kiedyś pięć konarów szkieletowych, odchodzących od pnia pod kątem $35-50^{\circ}$, z dobrze uformowanymi szerokimi pachwinami, z wykształconymi warstwami drewna reakcyjnego, praktycznie bez zakorka. Kształt pnia, ułożenia i odchylenia konarów wskazują, że drzewo od początku rosło samodzielnie i było fachowo podkrzesywane. Po latach, trzy spośród pięciu konarów ułożyły się prawie poziomo, zachowując łagodny łuk w bliskości pnia i rozrastając bardzo szeroko. Najdalej sięga obecnie konar odchodzący w kierunku północno-wschodnim $(12,5 \mathrm{~m})$. W kierunku południowo-wschodnim korona sięga do $10,7 \mathrm{~m}$, a na południe - $12 \mathrm{~m}$. Konar biegnący w stronę domu został w celu jego odciążenia przycięty w odległości 7,5 m od pnia. W miejscu cięcia, po prawidłowo wykonanej i uzasadnionej redukcji, widać bardzo szeroką obrączkę tkanki kalusowej (BoROwSKI 2016), na tworzenie której wpływa niewątpliwie silnie rozwijająca się pionowa gałąź o charakterze rejteracji (RoLOFF 2001). Jest to zjawisko interesujące, gdyż buki praktycznie nie mają zdolności odtwarzania korony (SIEWNIAK \& SIEWNIAK 2002). W listopadzie 2010 r. w dziupli powstałej w miejscu cięcia odnotowano obecność ptasich odchodów. W następnych latach jednak dziupla nie była zasiedlana.

Drzewo pod względem oceny żywotności weszło w fazę trzecią - rezygnacji, czyli zatrzymania wzrostu i degeneracji korony (ROLOFF 2001; SZEWCZYK 2012). Jednak po redukcji posuszu w szczytowej części korony (obniżonej z 22,5 do 17,5 m w 2018 r.), w wielu fragmentach widoczne są liczne nowe, drobne gałęzie. W 1962 r. buk miał $565 \mathrm{~cm}$, a w sierpniu 


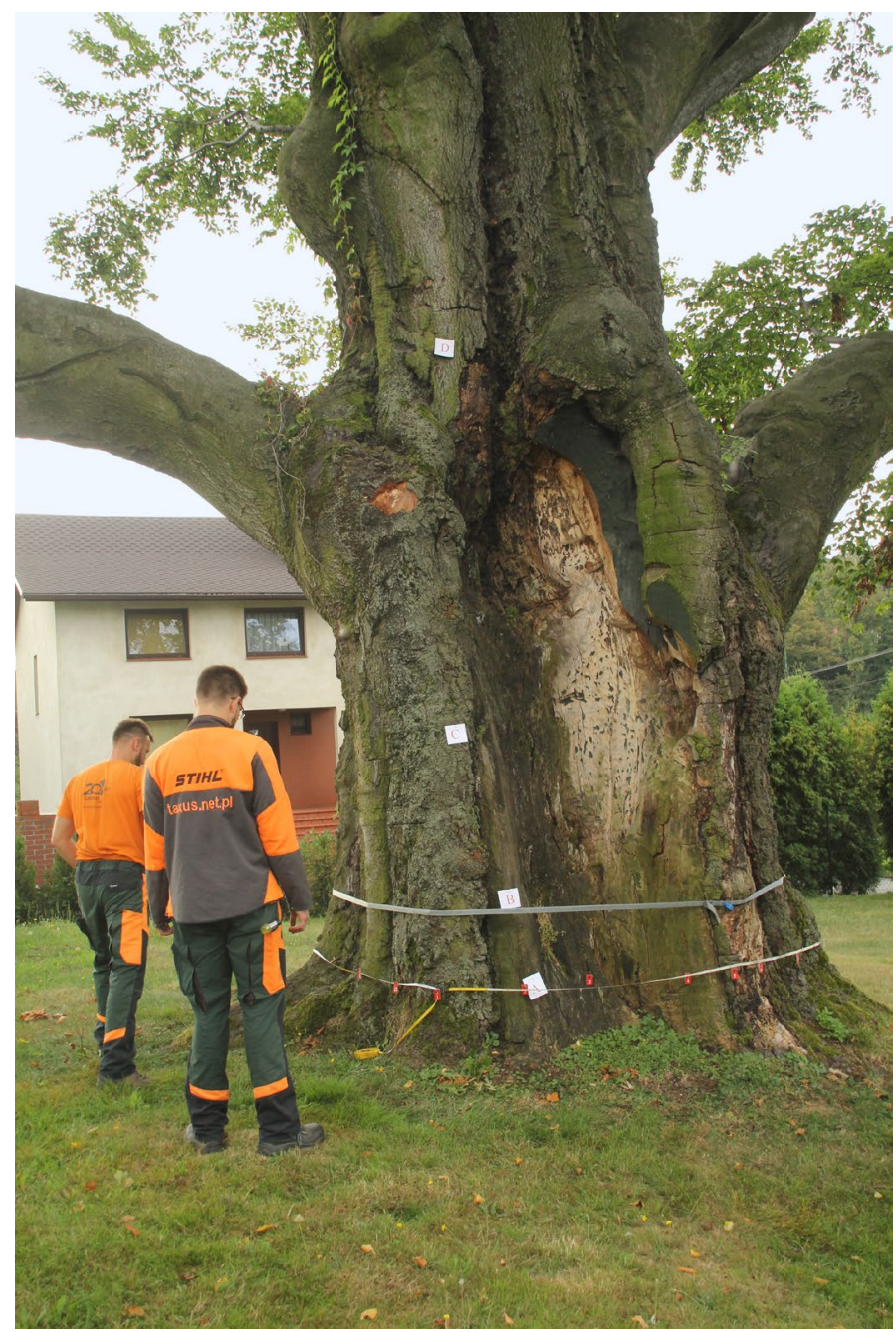

Ryc. 2. Pień buka od strony północno-zachodniej; zaznaczono poziomy badania tomograficznego na wysokości: 35 , 75 , 150 i $350 \mathrm{~cm}$ (fot. P. Muras)

Fig. 2. The beech trunk from the north-west side. Levels of tomographic examination are marked at $35,75,150$ and $350 \mathrm{~cm}$ height (photo P. Muras)

2018 r. - $732 \mathrm{~cm}$ obwodu pnia (w pierśnicy). Tak więc w ciągu 50 lat drzewo zwiększyło obwód o prawie $30 \%$. Świadczy to o jego ogromnym potencjale wzrostu.

Buk „Sobieski” wygląda na drzewo w doskonałym stanie zdrowotnym. Dokładne badanie wykazało jednak, oprócz istnienia po stronie północno-zachodniej płaszczyzny odsłoniętego drewna (Ryc. 2), dwa pionowe pęknięcia z wypróchnieniami od strony południowo-wschodniej, które biegną do połowy wysokości pnia. Korona utraciła też dwa potężne konary. Do wyłamania pierwszego konaru doszło w sierpniu 1979 r. (KuCZERA \& KUCZERA 2019). Mimo bardzo silnego kallusowania i prób wzmocnienia konstrukcji, co widać w postaci zgrubienia i napływu od strony północnej pnia, buk nie zabliźnił rany. 
Niewątpliwie ciężar i bardzo długie ramię konaru przyczyniło się do jego wyłamania, jednak daleko posunięty rozkład drewna w konarze sugeruje, że pierwotną przyczyną była infekcja, która rozpoczęła się w odziomku. Buk należy do gatunków mało odpornych na zgniliznę (CODER 1996; Kosmala i in. 2009). Powstałą ranę zabezpieczano poprzez sfrezowanie i pokrycie warstwą preparatu. W 2010 r. świeże pokrycie było pełne, poprawiono je w 2012 r. Obecnie powłoka ta utrzymuje się tylko w niewielkiej części (Ryc. 2), zaś na odkrytym drewnie w 2016 r. (na wysokości około $2 \mathrm{~m}$ ) stwierdzono owocniki szaroporki podpalanej (Bjerkandera adusta). W listopadzie 2012 r. około 0,5 m powyżej silnego kallusowania wokół rany po odpadniętym konarze, w niewielkiej szczelinie pojawiły się pojedyncze owocniki boczniaka (Pleurotus sp.). Badania zlecone przez Urząd Gminy Świerklany wykazały też obecność w tej części odziomka zgliszczaka pospolitego (Kretzschmaria deusta) (PUSTELNIK 2020), fakultatywnego pasożyta atakującego żywe drzewa, a później rosnącego na martwym drewnie (SuchOCKA \& BARIDON 2014). Obecność grzyba potwierdzono w sierpniu 2018 r. (GIEBUROwSKI i in. 2018). W jego sąsiedztwie, w przyziemiu, w odsłoniętym, spękanym i porażonym przez grzyba drewnie znaleziono ponad 30 otworów, wskazujących na żerowanie larw kózkowatych (Cerambycidae).

Drugi konar, od strony wschodniej, wyłamał się w lipcu 2017 r. Oględziny wykazały, że jego odziemna strona w części środkowej (3 m od pnia) była prawie w 1/3 porażona grzybnią. Na przekroju poprzecznym fragmentu odnotowano drewno reakcyjne oraz istnienie barier oddzielających fragmenty porażone. Drzewo nie wykazuje już zdolności do zabliźniania powstałej rany. Na odsłoniętym drewnie i powyżej miejsca odłamania pojawiają się liczne owocniki Bjerkandera adusta, a w szczelinach rozwijają się młode osobniki winobluszczu pięciolistkowego (Parthenocissus quinquefolia). W pęknięciu pionowym, biegnącym od podstawy pnia do szkieletowego konara odchodzącego w kierunku południowo-wschodnim, pojawiło się wypróchnienie otwarte, w którym w sierpniu 2018 r. zaobserwowano obficie rozrośnięte owocniki lakownicy spłaszczonej (Ganoderma applanatum) (GIEBUROwSKI i in. 2018). Gatunek ten był odnotowany w tym miejscu już w listopadzie 2012 r. Powodowana przez lakownicę zgnilizna rozszerza się na część peryferyjną i biel (SUCHOCKA \& BARIDON 2014).

Wykonana w sierpniu 2018 r. tomografia potwierdziła daleko posuniętą wewnętrzną destrukcję drewna i osłabienie struktur - zwłaszcza od przyziemia do około $3 \mathrm{~m}$ wysokości (Ryc. 3, 4). W części ,walcowatej” pnia, strefa dobrze zachowanego drewna nie przekracza (w rejonach pod zewnętrznie spójną korowiną) 20-30 cm. Na wysokości $350 \mathrm{~cm}$ odnotowano załamanie pnia w okolicy wyłamanego konaru. Najlepiej zachowane drewno występuje tutaj od strony południowej. Najmocniej uszkodzony, na wysokości $350 \mathrm{~cm}$ spękany fragment pnia obejmuje pas biegnący od rany po konarze odpadłym w 1997 r. do świeżej rany z 2017 r. (Ryc. 3) (GIEBUROwSKi i in. 2018).

Wstępna ocena wieku odpadłego w 2017 r. konaru (średnica $72 \mathrm{~cm}$ ) wykazała istnienie ponad 170 przyrostów rocznych. Biorąc pod uwagę wszystkie zebrane materiały, można szacować wiek buka na około 280-300 lat (P. Muras \& E. Muter, dane niepublikowane).

Buk rośnie na działce zamieszkałej, intensywnie użytkowanej i jest pod stałym nadzorem Gminy Świerklany. Wykonuje się na bieżąco cięcia sanitarne i pielęgnacyjne, dążąc do odciążenia korony. Ze względu na istniejące zagrożenie najbliższego otoczenia 


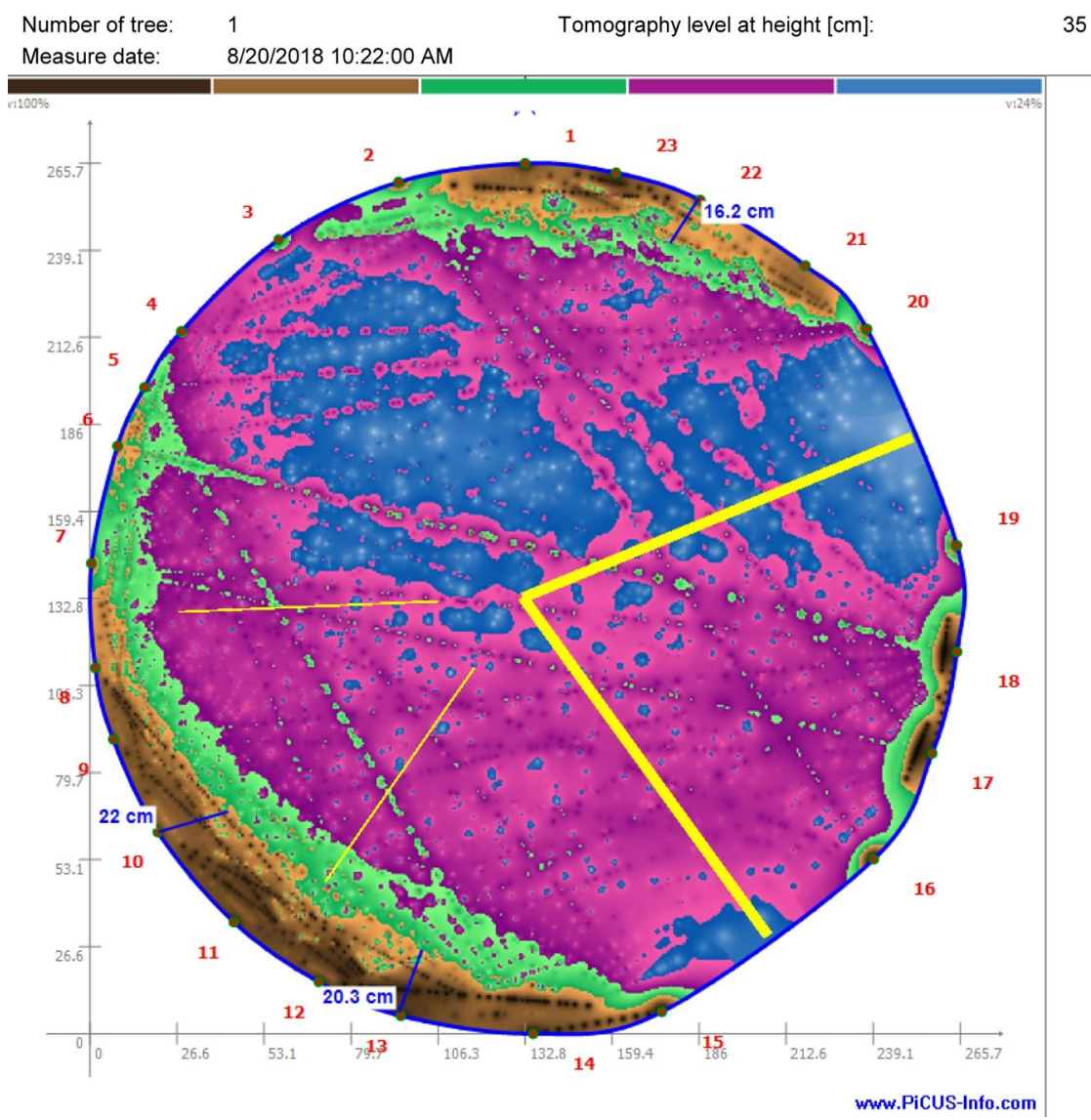

Ryc. 3. Obraz tomografii na wysokości $35 \mathrm{~cm}$. Stan pnia w sierpniu 2018 r. Północ w punkcie pomiarowym: 1. Wykonano: Taxus Arbor.

Widoczne na tomogramach obszary barwne określają stan zachowania drewna: kolor czarny oraz odcienie brązu - zdrowe drewno o właściwej strukturze; odcienie barwy zielonej - strefa przejściowa, gdzie struktura jest jeszcze dobra, lecz nieoptymalna; kolor różowy, fioletowy oraz ich odcienie - strefa znacznego osłabienia struktury drewna; zabarwienie niebieskie - brak powiązania mechanicznego z pozostałą częścią pnia, wypróchnienia lub mursz miękki; linie koloru żółtego - obecność wewnętrznych pęknięć lub duże wypróchnienia wewnętrzne; linie koloru niebieskiego z podaną skalą centymetrową pokazują szacowaną przez urządzenie szerokość zdrowej tkanki

Fig. 3. Tomographic image at $35 \mathrm{~cm}$ height. Trunk condition in August 2018. North at measuring point 1. Performed by Taxus Arbor.

Colors in tomographs are indicators of wood health: black and shades of brown - healthy wood with proper structure; shades of green -transition zone where the structure is still good but not optimal; pink, violet and their shades - zone of considerable weakening of wood structure; blue - lack of mechanical bond with the remaining part of the trunk, or soft rot; yellow lines - internal fissures or large rotten internal fragments; blue lines with a given centimeter scale show the device's estimated width of healthy tissue

drzewa, wzmocniono koronę wiązaniami elastycznymi. Prowadzi się ciągłe obserwacje i wykonuje badania tomograficzne (Pustelnik 2020). Ponieważ co roku zbiera się i wywozi opadłe liście, nie dochodzi do kumulacji w glebie próchnicy bukowej. Obecny trawnik gazonowy, regularnie i intensywnie koszony, uniemożliwił osiedlanie się gatunków leśnych. Jedynie w bezpośredniej bliskości u podstawy pnia po wschodniej stronie 


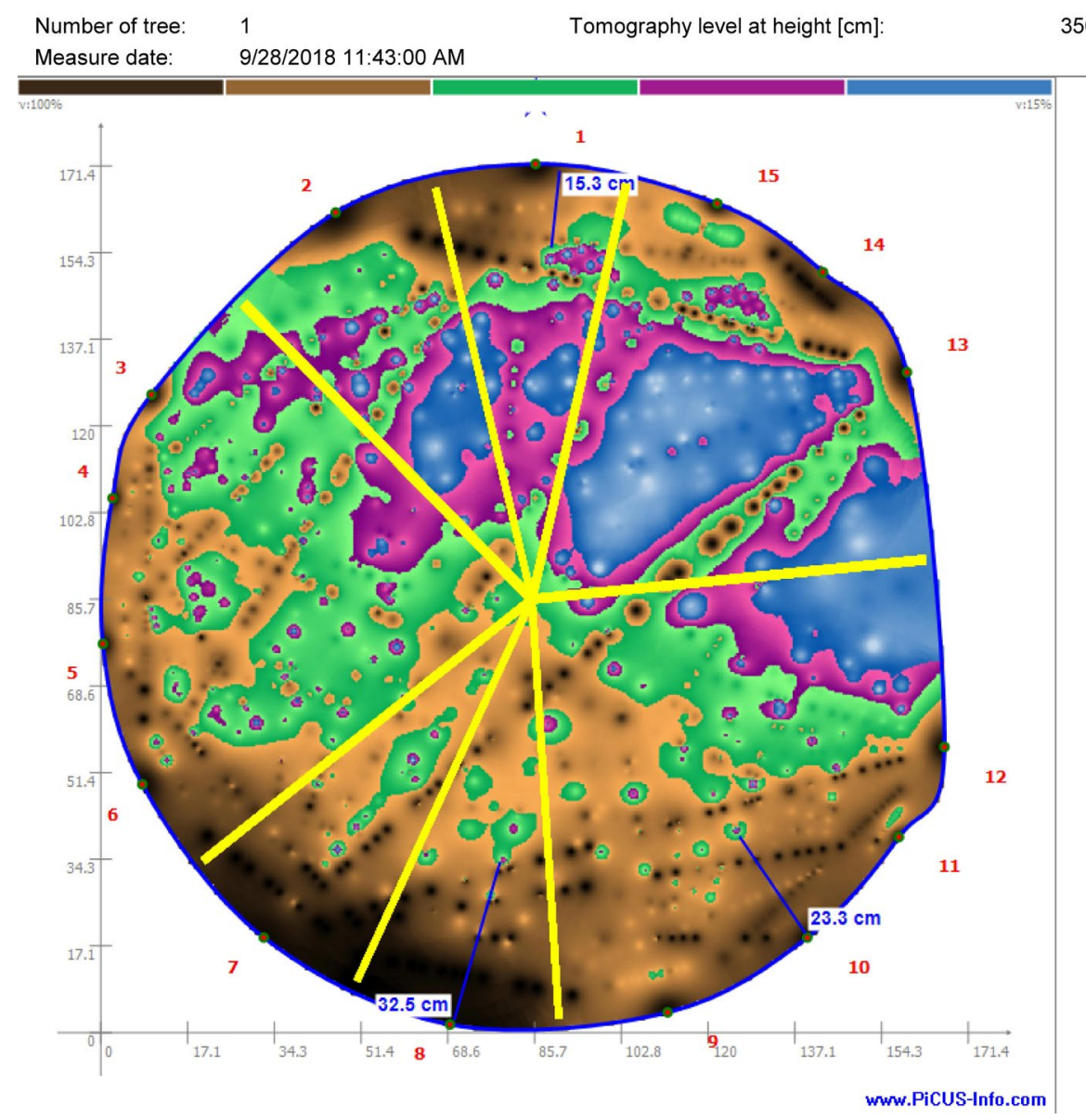

Ryc. 4. Obraz tomografii na wysokości $350 \mathrm{~cm}$. Stan pnia w sierpniu $2018 \mathrm{r}$. Północ w punkcie pomiarowym: 1. Wykonano: Taxus Arbor. Legenda jak na Ryc. 3

Fig. 4. Tomographic image at $350 \mathrm{~cm}$ height. Trunk condition in August 2018. North at measuring point 1. Performed by Taxus Arbor. Legend as in Fig. 3

odnotowano pojedyncze okazy narecznicy krótkoostnej (Dryopteris spinulosa) i siewkę bzu czarnego (Sambucus nigra). Wokół całego pnia rozrasta się bluszczyk kurdybanek (Glechoma hederacea).

W roku 2016 buk ,Sobieski” owocował obficie i w następnym roku stwierdzono w zasięgu korony liczne siewki (KuCZERA \& KuCZERA 2019). Obradzanie zdolnymi do kiełkowania nasionami przez około 300 letniego osobnika jest sprawą interesującą. Buk zasadniczo jest gatunkiem obcopylnym, owocuje nieregularnie, obficie zwykle co 5-10 lat, często rodząc bukiew płoną, nasiona są produkowane nawet przez drzewa ponad 200-letnie (SuSzKA i in. 2000). W przypadku „Sobieskiego” najbliższe liczne stanowiska dorodnych buków o obwodach przekraczających $350 \mathrm{~cm}$ znajdują się w Lesie Jankowickim (resztka Puszczy Pszczyńsko-Raciborskiej), w oddaleniu około $2 \mathrm{~km}$ na zachód od okazu pomnikowego. Stamtąd też wieją przeważające wiatry (około 50\%). 


\section{WNIOSKI}

Analiza warunków glebowych, klimatycznych, obecność dorodnych buków w południowej części Płaskowyżu Rybnickiego oraz osiągnięte parametry „Sobieskiego” wskazują, że na tym obszarze buk zwyczajny znajduje optymalne warunki do rozwoju. Jest to teren istnienia potencjalnej roślinności naturalnej w formie buczyny i grądu.

Wiek ,Sobieskiego" można szacować na około 300 lat. W sierpniu 2018 r. obwód pnia wynosił $732 \mathrm{~cm}$. Zestawienie źródeł czeskich i polskich pozwala na stwierdzenie, że w tej części Europy buk „Sobieski” jest najgrubszym żyjącym drzewem formy nominatywnej tego gatunku.

Buk „Sobieski” charakteryzuje się typowym dla drzew wyrosłych na otwartej przestrzeni krótkim, prostym i walcowatym masywnym pniem z potężnymi napływami korzeniowymi oraz rozłożystą, podniesioną przez podkrzesywanie pnia, koroną. Bez wątpienia drzewo zostało posadzone celowo na froncie nieistniejącego już dworu (gospody), a wybór miejsca był przemyślany.

Drzewo weszło już w ostatnią fazę rozwoju - rezygnację, czyli całkowite zahamowanie rozwoju, ma silnie obniżoną witalność i odrzuca fragmenty korony. Wyłamanie się konarów w 1979 i 2017 r., skutkujące powstaniem niezabliźnionych powierzchni oraz obecność groźnych patogenów i szkodników u podstawy pnia i w pionowych pęknięciach, wskazuje na daleko posuniętą destrukcję drewna i osłabienie struktury, co potwierdziła tomografia, wykonana w sierpniu $2018 \mathrm{r}$.

Podziękowania. Panom Wojciechowi Gieburowskiemu, Maciejowi Kozłowi i Piotrowi Żółkiewskiemu, pracownikom firmy Taxus Arbor Sp. z o.o. sp. k. w Tychach, dziękuję za wykonanie badań tomograficznych buka „Sobieski”. Pani Helenie i Markowi Kuczera wyrażam podziękowania za cenne informacje, poświęcony czas i możliwość wykonania badań, pomiarów i pobrania próbek buka. Panu Tadeuszowi Czarnuchowi, byłemu leśniczemu Lasu Jankowickiego, za pomoc w przeprowadzeniu wizji terenowej i w zebraniu materiału roślinnego. Panu Markowi Pustelnikowi za udostępnienie materiałów dotyczących zaangażowania Gminy Świerklany w opiekę nad bukiem „Sobieski”.

\section{LITERATURA}

Bıаєовок S. 1990. Ochrona drzew. - W: S. Bıаєовок (red.), Nasze drzewa leśne. 10, Buk zwyczajny Fagus sylvatica L., s. 615-652. Państwowe Wydawnictwo Naukowe, Warszawa - Poznań.

BoratyŃSKa K. \& BoRATYŃSKi A. 1990. Systematyka i geograficzne rozmieszczenie. - W: S. BiaŁoboK (red.), Nasze drzewa leśne. 10, Buk zwyczajny Fagus sylvatica L., s. 27-73. Państwowe Wydawnictwo Naukowe, Warszawa - Poznań.

Borowski J. 2016. Cięcie i pielęgnowanie drzew. - W: M. BIELA (red.), Tereny zieleni w mieście i ich uwarunkowania, s. 104-106. P.U.H.T.P. EKO-CHART, Katowice.

Сномісz E. 2010. Bezinwazyjne diagnozowanie kondycji drzew zabytkowych z zastosowaniem tomografów PiCUS@. Instrukcje. - Kurier Konserwatorski 8: 29-32.

CODER K. D. 1996. Construction damage assessments: trees and sites. s. 23. University of Georgia School of Forest Resources, Athens, Georgia.

Foltyn E. M. \& Foltyn E. 2017. Pradzieje i wczesne średniowiecze Rybnika z uwzględnieniem terenów przyległych. - W: Z. HoJKA \& B. KLOCH (red.), Rybnik. Dzieje miasta i jego dzielnic, s. 30-32. Muzeum w Rybniku, Rybnik. 
Gieburowski W., KozioŁ M. \& ŻóŁKIEwSKI P. 2018. Tomografia buka „Sobieski” w Świerklanach Dolnych. Picus Sonic Tomograph. Taxus Arbor Sp. z o.o. sp. k. z dnia 20.08.2018.

KondRaCKI J. 2000. Geografia regionalna Polski. s. 441. Wydawnictwo Naukowe PWN, Warszawa.

Kosmala M., RosŁon-SzeryńsKa E. \& Suchocka M. 2009. Influence of mechanical damage on the condition of trees. - Annals of Warsaw University of Life - SGGW, Horticulture and Landscape Architecture 29: 137-144.

KRUPA S. 2013. Stan zachowania materiałów archiwalnych z zasobu Archiwum Państwowego w Katowicach do dziejów przemarszu wojsk Jana III Sobieskiego przez Górny Śląsk w 1683 roku. - Szkice Archiwalno-Historyczne 10: 11-32.

KuCZERA H. \& KuCZera M. 2019. Informacje ustne właścicieli posesji na której rośnie buk Sobieski. Wywiad - P. Muras 15.10.2019 r.

Matuszkiewicz J. M. 2008. Potencjalna roślinność naturalna Polski. Instytut Geografii i Przestrzennego Zagospodarowania Polskiej Akademii Nauk, Warszawa. http://www.igipz.pan.pl/Roslinnosc-potencjalna-zgik.html (dostęp: 24.01.2020).

Milbrandt F. \& KöHLER M. 2015. Dendrologische Untersuchungen mittels Schallmessungen an ausgewählten Bäumen in der Wallanlage Neubrandenburgs. - ProBaum 2: 15-21.

MusioŁ J. 1959. Parafia Połomska (powiat wodzisławski). Monografia historyczna na źródłach oparta (maszynopis). s. 51-52. Połomia.

PIWARSKI K. 1934. Jan III Sobieski na Śląsku w r. 1683. - Roczniki Towarzystwa Nauk na Śląsku 4: 7-21.

Plan UrzązEnia Lasu. 2016. Regionalna Dyrekcja Lasów Państwowych w Katowicach. Nadleśnictwo Rybnik. Okres gospodarczy od 1.01.2017 do 31.12.2026. s. 41-46. Biuro Urządzania Lasu i Geodezji Leśnej, Oddział w Krakowie.

PustelniK P. 2020. Urząd Gminy Świerklany. Pismo RGP.6121.1.2020 z dnia 17.01.2020.

RoLOFF A. 2001. Baumkronen: Verständnis und praktische Bedeutung eines komplexen Naturphänomens. s. 26-56. Verlag Eugen Ulmer, Stuttgart.

Seneta W. \& Dolatowski J. 2009. Dendrologia. s. 140. Wydawnictwo Naukowe PWN, Warszawa.

SieWniaK M. \& SieWniaK M. 2002. European treeworker. s. 71. European Arboricultural Council (EAC). Patzer Verlag, Berlin - Hannnover.

SuCHOCKA M. \& BARIDON D. 2014. Przewodnik do identyfikacji gatunków grzybów pasożytniczych wraz z charakterystyką ich rozwoju oraz wpływu na statykę drzew. - W: K. WitKoś-GnACH \& P. Tyszko-CHMiElowiec (red.), Drzewa w krajobrazie - podręcznik praktyka, s. 91-114. Fundacja EkoRozwoju, Wrocław.

Suszka B., Muller C. \& Bonnet-Masimbert M. 2000. Nasiona leśnych drzew liściastych: od zbioru do siewu. s. 190-192. Wydawnictwo Naukowe PWN, Warszawa - Poznań.

SzEwCZYK G. 2012. Arborystyka: wybrane zagadnienia pielęgnacji drzew. s. 117-129. Wydawnictwo Uniwersytetu Rolniczego w Krakowie. Kraków.

ŚWIERKLANY. 2018. Warunki naturalne. - W: Internetowy serwis Gminy Świerklany. http://www. swierklany.pl/informacje-o-gminie/warunki-naturalne (dostęp: 20.04.2020).

Urbisz A. 2002. Drzewa pomnikowe Płaskowyżu Rybnickiego. - Natura Silesiae Superioris 6: 23-30.

ZARZYŃski P., Tomusiak R. \& Borkowski K. 2016. Drzewa Polski. Najgrubsze, najstarsze, najsłynniejsze. s. 145. Wydawnictwo Naukowe PWN, Warszawa.

ZıмoŃcZYK K. 1998a. Świerklany. Charakterystyka miejscowości. Działalność społeczno-wychowawcza w środowisku. s. 23. Wydawnictwo Księży Sercanów SCJ, Kraków.

ZıмоŃCZYK K. 1998b. Dzieje Świerklan w wypisach. s. 41. Wydawnictwo Księży Sercanów SCJ, Kraków. 


\section{SUMMARY}

The Sobieski" European beech known as "Sobieski", a nature monument since 1962, grows on private property in Świerklany Dolne (Fig. 1) in the southern part of the Rybnicki Plateau, at the beginning of the relatively wide and flat Szotkówka valley, which falls gently in the direction of the Olza Valley (Odra catchment). The area of Świerklany Górne and Świerklany Dolne is highly varied: relatively steep hilly fragments divide moist valleys which sometimes take the form of ravines. The land relief is the result of intensive ice sheet activity. In the Świerklany Dolne area, clay and loess-like formations dominate. In the Szotkówka valley, very fertile fluvic phaeozems developed from silt and clay, with occasional impermeable layers beneath, which make tillage difficult in wet summers. At the same time they create ideal conditions for ponds, which have existed there since the Middle Ages. There are groups of black alders along the Szotkówka brook. In the 1970s, mighty ash trees still grew along Route 932. Riparian forest is a potential and natural form of vegetation in this part of the valley.

The "Sobieski" beech grows on fertile soils with constant supply of water. The place is well sheltered from north-western and eastern winds. In such a habitat, age estimation is not easy. What is more, the poor condition of the inside of the trunk makes drill core examination doubtful. In 2017, samples for dendrochronological analysis were taken from a broken bough from 3-4 m height. Even a preliminary assessment revealed 170 annual rings, so the age of that beech can be estimated at 300 years. In August 2018 the trunk circumference at breast height was $732 \mathrm{~cm}$ (Fig. 2). "Sobieski" has increased its circumference by $30 \%$ since the 1960 s, which indicates the tree's enormous potential and vigour. The beech has a short, cylindrical, solid trunk, with huge buttress roots typical for trees growing in open space. At 4-5 m height the trunk divides into several thick boughs forming a spreading crown. Trunk thickness, the height at which the crown begins, and the location of the tree on the southern side of the manor clearly indicates that "Sobieski" was planted there deliberately on a selected site and that the tree was subjected to crown training. On the surface the tree seems to be in excellent health, but fruiting bodies of Ganoderma fungus on the vertically cracked trunk indicate that the wood inside probably is in an advanced state of decomposition. Although the has tree reached its third and final life stage and is shedding crown fragments, it produces callus abundantly in the cut areas and is making remarkable attempts to rebuild the crown fragments. Unfortunately, the breaking of boughs in 1979 and 2017, the presence of open wounds, as well as the tomographic examination performed in July 2018 by the Taxus Arbor Company, confirmed advanced decomposition of internal wood and structural weakening (Figs 3, 4).

The "Sobieski" beech is constantly monitored by the local authorities of Świerklany. Dead branches were removed during sanitation cuttings and pruning, and the crown was strengthened with elastic bindings. Dendrological observations and tomographic examinations are regularly carried out to assess hazards. Analysis of forest areas in the middle of the Rybnicki Mesoregion, remnants of the Pszczyńsko-Raciborska primeval forest (including Jankowicki Forest), revealed the presence of a group of magnificent beeches. Taking into account the $2 \mathrm{~km}$ kilometre distance between a forest complex and "Sobieski", growing in a deforested area since the Middle Ages, there is very likely a genetic relationship between "Sobieski" and that group of old trees of the same species within the forest complex. To test that assumption, genetic samples were taken to evaluate the degree of genetic relationship or the presence of alleles unique to the tree monument. That research is in progress.

Analyses of soil and climate conditions as well as the presence of mighty beeches in the southern part of the Rybnicki Plateau indicate that the healthy development of the "Sobieski" beech may be due to optimal regional conditions for the growth of that species. The habitat is suitable for potential and natural vegetation of beech and oak-hornbeam forests similar to the area of eastern Moravia. Forests, similar to conditions in eastern Moravia. An analysis of archives neither proves or disproves a direct historical link between the tree growing next to the no longer extant Kundlauer Manor and the march of King John III Sobieski's army through Upper Silesia in 1683.

Wptynęto: 11.02.2020 r.; przyjęto do druku: 17.04.2020 r. 